\title{
Effect of Gibberellic Acid and Assisted Pollination on Fruit Characters of Custard Apple cv. Arka Sahan
}

\author{
A.P. Shivakumar ${ }^{1 *}$, Venkata Rao ${ }^{2}$, M.K. Honnabyraiah ${ }^{1}$, T. Sakthivel ${ }^{3}$, \\ S.V. Patil ${ }^{4}$, K.R. Vasudeva ${ }^{5}$, J. Dinakara Adiga ${ }^{6}$ and H. S. Srikanth ${ }^{1}$ \\ ${ }^{1}$ Department of Fruit Science, College of Horticulture, Bengaluru, Karnataka, India \\ ${ }^{2}$ Department of Fruit Science, College of Horticulture, Mysore, Karnataka, India \\ ${ }^{3}$ Division of Fruit crops, ICAR - IIHR, Bengaluru, Karnataka, India \\ ${ }^{4}$ Department of Agronomy, RHREC, UHS, Campus, Bengaluru, Karnataka, India \\ ${ }^{5}$ Department of Postharvest Technology, College of Horticulture, Bengaluru, Karnataka, India \\ ${ }^{6}$ Division of Horticulture, ICAR - DCR, Puttur, Karnataka, India \\ *Corresponding author
}

\section{A B S T R A C T}

\begin{tabular}{|l|}
\hline K e y w o r d s \\
Gibberellic acid, Assisted \\
pollination, Pulp \\
recovery, Seed content
\end{tabular}

\section{Introduction}

Custard apple is one of the important minor fruit crop grown across the tropical and subtropical tracts of India. These fruit crop possesses unique pleasant flavour, mild aroma and sweet taste have a universal acceptance.

Annona fruits have considerable importance in human nutrition, medicinal and cultural events (Thakur and Singh, 1967). The most important among them is custard apple (Annona squamosa L.). Arka Sahan one of the popular
Arka Sahan is one of important variety of custard apple. It is popular because of its exhalent flavour and taste. The present experiment was carried out mainly to enhance fruit weight, pulp recovery and reduce the seed. The study under taken in Regional Horticultural Research and Extension Station, University of Horticultural Sciences campus, Bengaluru. The study revealed that the combination of $\mathrm{GA}_{3} 1000 \mathrm{ppm}+$ assisted pollination recorded maximum increment in fruit weight $(409.13 \mathrm{~g})$, pulp weight $(307.90 \mathrm{~g})$, Pulp recovery (75.21\%), Pulp: Peel ratio (4.63) and Pulp: seed ratio (23.12). The study also recorded lowest Peel content (12.25\%) and Seed content $(3.24 \%)$ in the treatment $\mathrm{A}_{3} 1000 \mathrm{ppm}+$ Hand pollination. Among different treatment the combination of $\mathrm{GA}_{3}$ $1000 \mathrm{ppm}+$ assisted pollination shows best result in custard apple $c v$. Arka sahan. 
uniformity desired by the consumer market when they are pollinated artificially. However, these fruits have relatively high costs associated with labour (Janick and Paul, 2006). Studies have shown that seedless ness in many species may be promoted through the application of gibberellins, auxins and cytokinins, without requiring pollination. Considering the above aspects, an investigation was carried out with an objective of increase in pulp recovery and reduce number of seed.

\section{Materials and Methods}

The present study was conducted at Regional Horticultural Research and Extension Centre, College of Horticulture, University of Horticultural Sciences, GKVK campus, Bengaluru in a randomized complete block design, five year old uniform plant was selected. For the current experiment were experimented mainly for the better results of fruit characters by treating custard apple with assisted pollination alone and combination of various treatments of Gibberellic acid (500 ppm, 1000 ppm, 1500 ppm and 2000 ppm). The control treatment was plain water sprayed without assisted pollination and Gibberellic acid.

Preparation of $\mathrm{GA}_{3}$ solution and spraying details

Based on the treatment details, $\mathrm{GA}_{3}$ solutions of different concentration were prepared by weighing required gram of $\mathrm{GA}_{3}$, dissolved in little quantity of Ethanol and make up volume to $1000 \mathrm{ml}$ by using distil water. Spraying details of the study is as fallows for treatments with hand pollination, the sprays was taken at $1^{\text {st }}, 3^{\text {rd }}$ and $5^{\text {th }}$ week after pollination whereas, for treatments with no artificial pollination, the sprays was given at the time of anthesis followed by 1st, 3rd and 5th week after anthesis.
The observations on various fruit characters were recorded in five randomly selected fruit per replication in each treatment. Fruit character like Fruit weight (g), Pulp weight (g), Peel weight (g) and seed weight (g) was recorded using electronic weighing balance. Other parameters like number of seed per fruit is counted manually and average of five fruit is taken in each treatment while pulp recovery $(\%)$, peel content $(\%)$ and seed content $(\%)$ were calculated by following formulas:

$$
\begin{aligned}
& \text { Pulp weight } \\
& \text { Pulp recovery }(\%)=\frac{\text {--------------- } \times 100}{\text { Fruit weight }} \\
& \text { Peel content }(\%)=\frac{\text { Peel weight }}{\text { Fruit weight }} \times 100 \\
& \text { Seed content }(\%)=\frac{\text { Seed weight }}{\text { Fruit weight }} \times 100
\end{aligned}
$$

\section{Statistical analysis}

The data on various parameters during the course of investigation were statistically analyzed, applying the technique of analysis of variance suggested by Panse and Sukhatme, (1985). Wherever, the treatment differences were found significant, (F-test) critical difference was worked out at five per cent probability level. The treatment differences that were not significant were denoted by "NS".

\section{Results and Discussion}

\section{Fruit weight (g)}

The effect of Gibberellic acid and assisted pollination on fruit weight found to be statistically significant among the various treatments (Table 1). From the obtained results it was observed that the maximum fruit 
weight (409.13 g) in $\mathrm{GA}_{3} 1000 \mathrm{ppm}+$ Hand pollination which was on par with $\mathrm{GA}_{3} 1500$ ppm + Hand pollination (362.68 g). Whereas, the minimum fruit weight $(181.81 \mathrm{~g})$ was recorded from Control which was on par with $\mathrm{GA}_{3} 500 \mathrm{ppm}(220.60 \mathrm{~g})$. The fruit weight here may be directly attributed by the exogenous supply of Gibberellic acid, where it increases the cell division and cell elongation.

The foliar application of growth regulators which helps in active polar transport, promote cell multiplication and enlargement of cells and more accumulation of food materials like sugars and water in expanded cells. The similar results were also recorded by Chaudhary et al., (2014), Patel et al., (2010) in custard apple and Katiyar et al., (2008), Garasiya et al., (2013) in guava.

\section{Pulp weight (g)}

The data regarding pulp weight has been presented in Table 1. As evident from the data, significant differences were observed among the treatments. The highest pulp weight $(307.90 \mathrm{~g})$ was found from $\mathrm{GA}_{3} 1000 \mathrm{ppm}+$ Hand pollination which were on par with $\mathrm{GA}_{3}$ $1500 \mathrm{ppm}+$ Hand pollination (273.58 g). Whereas, the lowest pulp weight (128.49 g) was observed in Control which was on par with $\mathrm{GA}_{3} 500$ ppm (122.59 g).

The increase in pulp weight may also be due to increased berry weight coupled with induced cell division and assimilate mobilization in the developing berries as reported by Rizk et al., (2011) in grapes, similarly Ramezani and Shekafandeh (2009) reported that the increase in pulp weight in olive might be due to application of $\mathrm{GA}_{3}$ which helps in increasing the fruit mesocarp could be interpreted through its action on sink demand by enhancement of phloem unloading or the metabolism of carbon assimilates in fruit.

\section{Peel weight (g)}

From the analysed data it was observed that the minimum peel weight from the treatment Control (38.63 g) which was followed by $\mathrm{GA}_{3}$ 500 ppm and $\mathrm{GA}_{3} 1500$ ppm (49.74 and 50.91 $\mathrm{g}$, respectively).

The maximum peel weight $(66.78 \mathrm{~g})$ was observed from the treatment combination of $\mathrm{GA}_{3} 1000 \mathrm{ppm}+$ Hand pollination which was on par with $\mathrm{GA}_{3} 500 \mathrm{ppm}+$ Hand pollination, $\mathrm{GA}_{3} 1500 \mathrm{ppm}+$ Hand pollination, and $\mathrm{GA}_{3}$ 2000 ppm + Hand pollination (65.15, 64.38 and $61.97 \mathrm{~g}$ respectively) as represented in Table 1.

The increase in peel weight in other treatment is may be due to more cell division by $\mathrm{GA}_{3}$, thereby increasing the cell density per unit volume (Bhat et al., 2012). The findings are in close conformity with earlier reports (Peng et al., 2004 and Gomes et al., 2006).

\section{Pulp recovery $(\%)$}

The obtained data regarding pulp recovery were found to be statistically significant among the various treatments.

The highest pulp recovery $(75.21 \%)$ was obtained from $\mathrm{GA}_{3} 1000 \mathrm{ppm}+$ Hand pollination which was on par with $\mathrm{GA}_{3} 1500$ ppm + Hand pollination, $\mathrm{GA}_{3} 500 \mathrm{ppm}+$ Hand pollination and $\mathrm{GA}_{3} 2000 \mathrm{ppm}+$ Hand pollination $(72.40, \quad 71.24$ and $70.65 \%$ respectively).

Meanwhile, the lowest pulp recovery (57.60 $\%$ ) in (Control) which was on par with $\mathrm{GA}_{3}$ $500 \mathrm{ppm}(53.96 \%)$. The increase in the pulp content mainly dependent on the exogenous supply of Gibberellic acid than hand pollination because the Gibberellic acid increases the overall fruit weight due to increase in the mesophyll cells of the fruit. 
Table.1 Effect of gibberellic acid and assisted pollination on Pulp and Peel quantity of custard apple $c v$. Arka Sahan

\begin{tabular}{|c|c|c|c|c|c|c|}
\hline Treatments & $\begin{array}{l}\text { Fruit } \\
\text { weight } \\
\text { (g) }\end{array}$ & $\begin{array}{l}\text { Pulp } \\
\text { weight } \\
\text { (g) }\end{array}$ & $\begin{array}{c}\text { Peel } \\
\text { weight } \\
(\mathrm{g})\end{array}$ & $\begin{array}{c}\text { Pulp } \\
\text { recovery } \\
(\%)\end{array}$ & $\begin{array}{c}\text { Peel } \\
\text { content } \\
(\%)\end{array}$ & $\begin{array}{c}\text { Pulp: Peel } \\
\text { ratio }\end{array}$ \\
\hline $\mathrm{T}_{1}$ : Hand pollination & 274.49 & 171.31 & 59.58 & 63.91 & 16.38 & 2.84 \\
\hline $\mathrm{T}_{2}: \mathrm{GA}_{3} \mathbf{5 0 0 p p m}$ & 220.60 & 122.59 & 49.74 & 53.96 & 15.78 & 2.44 \\
\hline $\mathrm{T}_{3}: \mathrm{GA}_{3}$ 1000ppm & 262.60 & 157.49 & 51.82 & 62.67 & 14.11 & 3.01 \\
\hline $\mathrm{T}_{4}: \mathrm{GA}_{3}$ 1500ppm & 260.83 & 168.67 & 50.91 & 65.44 & 13.88 & 3.32 \\
\hline $\mathrm{T}_{5}: \mathrm{GA}_{3} 2000 \mathrm{ppm}$ & 278.72 & 193.46 & 50.76 & 68.56 & 13.09 & 3.78 \\
\hline $\mathrm{T}_{6}: \mathrm{GA}_{3} 500 \mathrm{ppm}+$ Hand pollination & 346.54 & 218.24 & 65.15 & 71.24 & 14.50 & 3.33 \\
\hline $\mathrm{T}_{7}: \mathbf{G A}_{3} \mathbf{1 0 0 0 p p m}+$ Hand pollination & 409.13 & 307.90 & 66.78 & 75.21 & 12.25 & 4.63 \\
\hline $\mathrm{T}_{8}: \mathbf{G A}_{3}$ 1500ppm + Hand pollination & 362.68 & 273.58 & 64.38 & 72.40 & 13.18 & 4.21 \\
\hline $\mathrm{T}_{9}: \mathrm{GA}_{3} 2000 \mathrm{ppm}+$ Hand pollination & 343.16 & 251.65 & 61.97 & 70.65 & 15.26 & 4.02 \\
\hline $\mathrm{T}_{10}:$ Control & 181.81 & 128.49 & 38.63 & 57.60 & 13.96 & 3.32 \\
\hline S. Em. \pm & 16.67 & 11.86 & 3.22 & 3.23 & 0.36 & 0.23 \\
\hline CD@ 5\% & 49.53 & 35.23 & 9.57 & 9.59 & 1.06 & 0.68 \\
\hline
\end{tabular}

Table.2 Effect of gibberellic acid and assisted pollination on seed characteristics of custard apple $c v$. Arka Sahan

\begin{tabular}{|c|c|c|c|c|}
\hline Treatments & $\begin{array}{c}\text { Number of } \\
\text { seeds per fruit }\end{array}$ & $\begin{array}{l}\text { Seed weight per } \\
\text { fruit(g) }\end{array}$ & $\begin{array}{c}\text { Seed content } \\
(\%)\end{array}$ & $\begin{array}{l}\text { Pulp: seed } \\
\text { ratio }\end{array}$ \\
\hline $\mathrm{T}_{1}$ : Hand pollination & 35.33 & 18.24 & 6.64 & 9.52 \\
\hline $\mathrm{T}_{2}: \mathrm{GA}_{3}$ 500ppm & 31.60 & 16.23 & 7.34 & 7.38 \\
\hline $\mathrm{T}_{3}: \mathrm{GA}_{3}$ 1000ppm & 31.93 & 16.63 & 6.33 & 9.45 \\
\hline $\mathrm{T}_{4}: \mathrm{GA}_{3}$ 1500ppm & 30.20 & 15.92 & 6.17 & 10.39 \\
\hline$T_{5}: G_{3} 2000 p p m$ & 30.27 & 16.04 & 5.72 & 12.13 \\
\hline $\mathrm{T}_{6}: \mathrm{GA}_{3} 500 \mathrm{ppm}+$ Hand pollination & 33.80 & 16.65 & 4.73 & 13.15 \\
\hline $\mathrm{T}_{7}: \mathrm{GA}_{3}$ 1000ppm + Hand pollination & 27.80 & 13.30 & 3.24 & 23.12 \\
\hline $\mathrm{T}_{8}: \mathrm{GA}_{3}$ 1500ppm + Hand pollination & 32.40 & 15.40 & 4.23 & 17.51 \\
\hline $\mathrm{T}_{9}: \mathrm{GA}_{3}$ 2000ppm + Hand pollination & 31.20 & 16.08 & 4.65 & 15.53 \\
\hline$T_{10}$ : Control & 15.07 & 9.40 & 5.18 & 13.47 \\
\hline S. Em. \pm & 1.81 & 0.80 & 0.41 & 0.81 \\
\hline CD@ 5\% & 5.46 & 2.38 & 1.22 & 2.40 \\
\hline
\end{tabular}

The similar conformational statements were also being given by Zhang et al., (2007) that the increase in fruit size in pear in response to exogenously applied $\mathrm{GA}_{3}$ and this has been associated with an increase in cell size of the mesocarp and increased sink demand by the enhancement of phloem unloading or metabolism of carbon assimilates in fruit.

\section{Peel content (\%)}

The analysed data on peel content (\%) are presented in Table 1 and observed significant differences among the treatments. The data revealed that the lowest peel percentage $(12.25 \%)$ from $\mathrm{GA}_{3} 1000 \mathrm{ppm}+$ Hand pollination which was on par with $\mathrm{GA}_{3} 1500$ 
ppm + Hand pollination (13.18\%). Whereas, the highest pulp percentage $(16.38 \%)$ was observed in Hand pollination which was on par with $\mathrm{GA}_{3} 500$ ppm $(15.78 \%)$.

\section{Pulp: Peel ratio}

The highest pulp: peel ratio (4.63) was obtained in $\mathrm{GA}_{3} 1000 \mathrm{ppm}+$ Hand pollination which was on par with $\mathrm{GA}_{3} 1500 \mathrm{ppm}+$ Hand pollination and $\mathrm{GA}_{3} 2000 \mathrm{ppm}+$ Hand pollination (4.21 and 4.02 respectively).

The lowest pulp: peel (2.44) was recorded in $\mathrm{GA}_{3} 500$ which was on par with Hand pollination and $\mathrm{GA}_{3} 1000$ (2.84 and 3.01 respectively). This result due to the combined application of growth regulators which will increase the pulp ratio by cell division and cell elongation.

\section{Number of seeds per fruit}

The number of seeds per fruit was found to be significant among various treatments and presented in Table 2. The lowest number of seeds per fruit (15.07) was recorded from Control which was followed by $\mathrm{GA}_{3} 1000$ $\mathrm{ppm}+$ Hand pollination, $\mathrm{GA}_{3} 1500 \mathrm{ppm}$ and $\mathrm{GA}_{3} 2000$ ppm (27.80, 30.20 and 30.27 respectively).

The highest number of seeds per fruit (35.33) was reported from Hand pollination which was on par with $\mathrm{GA}_{3} 1500 \mathrm{ppm}+$ Hand pollination and $\mathrm{GA}_{3} 1000$ ppm (32.40 and 31.93 respectively). This reduction in number of seeds per fruit might be attributed to the natural pollination where by the pollen of the mother parent fertilized its own flowers. As evident from our experimental results the naturally pollinated fruit does not exceed 15.07 seeds per fruit. This is in confirmation with the results of Jalikop (2010), who also reported the lower number of seeds upon natural pollination.

\section{Seed weight per fruit (g)}

The results showed significant differences among the treatments. The observed data revealed that the lowest seed weight per fruit $(9.40 \mathrm{~g})$ from Control followed by $\mathrm{GA}_{3} 1000$ ppm + Hand pollination and $\mathrm{GA}_{3} 1500 \mathrm{ppm}+$ Hand pollination (13.30 g and $15.40 \mathrm{~g})$. The highest seed weight per fruit (18.24 g) was observed in Hand pollination which was on par with $\mathrm{GA}_{3} 2000$ and $\mathrm{GA}_{3} 1500$ (16.65 g and $16.04 \mathrm{~g}$ ). From the above observation it is clear that as the total number of seeds decreases proportionately the seed weight per fruit also decreases. The similar results were also made by Jalikop, (2010), who report the minimum seed weight from the naturally pollinated fruits.

\section{Seed content $(\%)$}

The data related to seed content $(\%)$ are presented in the Table 2. The results showed significant differences among the treatments. The $\mathrm{GA}_{3} 1000 \mathrm{ppm}+$ Hand pollination has recorded minimum $(3.24 \%)$ seed content followed by $\mathrm{GA}_{3} 1500 \mathrm{ppm}+$ Hand pollination and $\mathrm{GA}_{3} 2000 \mathrm{ppm}+$ Hand pollination ( $4.23 \%$ and $4.65 \%)$. The highest seed content $(7.34 \%)$ was observed from $\mathrm{GA}_{3} 500$ ppm which was on par with Hand pollination and $\mathrm{GA}_{3} 1000 \mathrm{ppm}(6.64 \%$ and $6.33 \%)$. This might be due to exogenous supply of Gibberellic acid which imparts parthenocarpy in treated fruits. Such instances of reduced seed number due to $\mathrm{GA}_{3}$ or other growth regulators were reported earlier by Dass and Randhawa (1968), Patil et al., (2010) in sapota and Bhat et al., (2012) in grapes. Paleg (1960) reported that exogenous application of growth regulators like $\mathrm{GA}_{3}$ and other may induce amylolytic activity in isolated endosperm which resulted in the formation and release of reducing sugars. This amylolytic splitting of the nutrients of the endosperm as well as the nucellus could 
deprive the developing embryo of the metabolites required for its further growth and differentiation and thus resulting in its abortion.

\section{Pulp: seed ratio}

The maximum pulp to seed ratio (23.12) was observed in $\mathrm{GA}_{3} 1000 \mathrm{ppm}+$ Hand pollination followed by $\mathrm{GA}_{3} 1500 \mathrm{ppm}+$ Hand pollination and $\mathrm{GA}_{3} 2000 \mathrm{ppm}+$ Hand pollination (17.51 and 15.53). The minimum pulp to seed ratio (7.38) was recorded from $\mathrm{GA}_{3} 500 \mathrm{ppm}$. This might be due to the combined application of growth regulators which will increase the pulp ratio by cell division and cell elongation and it will also play important role in reducing seed number in the fruit when applied after fertilization. The similar results were also reported by Santos et al., (2016) that fruits artificially pollinated and treated with three and two $\mathrm{GA}_{3}$ applications after anthesis showed a remarkable reduction in seed ratios, with no dose effect.

The present experiment is evident that Gibberellic acid alone cannot have a significant enhancement in the fruit characters development of Arka Sahan, it is the combined effect of artificial pollination and gibberellic acid. Among the observed results we can conclude that the exogenous application of $\mathrm{GA}_{3}$ 1000ppm and assisted pollination was found to best in increment in fruit character and also reduces the seed in custard apple $c v$. Arka Sahan.

\section{References}

Bhat, Z. A., Rashid, R. and Bhat, J. A., 2012, Effect of plant growth regulators on leaf number, leaf area and leaf dry matter in grape. Nat. Sci. Bio., 3(1): 87-90.

Campbell, C. W., and Phillips, R.L., 1994. The atemoya. Gainesville, Florida:
Horticultural Sciences Department, Florida Cooperative Extension Service, Institute of Food and Agricultural Sciences, University of Florida.

Chaudhary, J. C., Patel, K. D., Yadav, L., Patel, U. I. and Varu, D. K., 2014, Effect of plant growth regulators on flowering, fruit set and yield of custard apple (Annonasquamosa L.) $c v$. Sindhan. Adv. in Life Sci. 5(4): 12021204.

Garasiya, V. R., Patel, N. M., Bhadauria, H. S. and Wankhade, V. R., 2013, Effect of plant growth regulators on quality of winter season guava (Psidium guajava L.) $c v$. L-49. Asian J. Hort., 8(1): 347349.

Gomes, M.M.A., Campostrini, E., Leal, N.R., Viana, A.P., Ferraz, T.M., Siqueira, N.D. and Ros, R.C.C., 2006,Brassinosteroid analogue effects on the yield of yellow passion fruit plants (Passiflora edulisf. flavicarpa), Sci. Hortic., 110: 235-240.

Jalikop, S. H., 2010, Tree and fruit traits of progenies from the cross between (Annona cherimola Mill., A. squamosa $\mathrm{L}, A$. reticulataL and approaches for the introgression of valuable genes from $A$. reticulata L. Euphytica173:161-171.

Janick, J. and Paul, R.E., 2008. The Encyclopedia of Fruits and Nuts. Cambridge, MA. CABI.

Panse, V. G. and Sukhatme, P. V., 1985, Statistical methods for agricultural workers. ICAR, New Delhi.

Patel, N.M., Patel, D.K., Varma, L.R. and Patel, M.M., (2010), Effect of cultural and chemical treatments on fruit set and fruit yield of custard apple (Annona squamosa, Linn) $c v$. Sindhan. Asian J. of Hort., 5(2):498-502.

Peng, J., Tang and Feng, H., 2004, Effects of Brassinolide treatment on the physiological properties of litchi 
pericarp (Litchi chinensis) $c v$. Nuomoci, Sci. Hortic., 101:407-416.

Ramezani, S. and Shekafandeh, A., 2009, Roles of gibberellic acid and zinc sulphate in increasing size and weight of olive fruit. African J. Biotechnol., 8(24):6791-6794.

Rizk, A. M. S., Abd El-Wahab, M. A. and Fekry, O. M., 2011, Application of $\mathrm{ga}_{3}$ and naa as a means for improving yield, fruit quality and storability of Black Monukka grape. Nature and Sci., 9(1): $1-19$.

Santos, R. C. D., Pereira, M. C. T., Mendes, D. S., Sobral, R. R. S., Nietsche, S., Mizobutsi, G. P. and Santos, B. H. C.
D., 2016, Gibberellic acid induces parthenocarpy and increases fruit size in the 'Gefner' custard apple (Annona cherimolax Annona squamosa). Australian J. Crop Sci., 10 (3): 314-321. Thakur, D. R. and Singh, R. N., 1967, Pomological description and classification of some annona. Indian J. Hort., 24: 11-19.

Zhang, C., Tanabe, K., Tani, H., Nakajima, H., Mori, M., Itai, A., Sakuno, E., 2007. Biologically active gibberellins and abscisic acid in fruit of two latematuring Japanese pear cultivars with contrasting fruit size. J. American Soc. Hort. Sci., 132: 452-458.

\section{How to cite this article:}

Shivakumar, A.P., Venkata Rao, M.K. Honnabyraiah, T. Sakthivel, S.V. Patil, K.R. Vasudeva, J. Dinakara Adiga and Srikanth, H. S. 2018. Effect of Gibberellic Acid and Assisted Pollination on Fruit Characters of Custard Apple cv. Arka Sahan. Int.J.Curr.Microbiol.App.Sci. 7(08): 2543-2549. doi: https://doi.org/10.20546/ijcmas.2018.708.260 